\title{
Scat detection dogs, DNA and species distribution modelling reveal a diminutive geographical range for the Vulnerable small red brocket deer Mazama bororo
}

\author{
José Maurício Barbanti Duarte, Ângela Cristina Talarico \\ Alexandre Vogliotti, José Eduardo Garcia, Márcio Leite Oliveira \\ JEsús E. Maldonado and Susana González
}

\begin{abstract}
The small red brocket deer Mazama bororo is endemic to the Brazilian Atlantic Forest, a biome that has been greatly fragmented and altered by human activities. This elusive species is morphologically similar to the red brocket deer Mazama americana and the Brazilian dwarf brocket deer Mazama nana, and genetic typing is necessary for reliable identification. To determine the geographical range of $M$. bororo more accurately, we conducted non-invasive genetic sampling using scat detection dogs trained to locate deer faeces. We surveyed 46 protected areas located within the species' potential distribution and collected a total of 555 scat samples in 30 of the protected areas. Using a polymerase chain reaction-restriction fragment length polymorphism approach, we genotyped 497 scat samples $(89 \%)$ and detected M. bororo in seven localities in three Brazilian states. The results support a range extension of the small red brocket deer to latitudes 23 and $28^{\circ} \mathrm{S}$ and longitudes 47 and $49^{\circ} \mathrm{W}$. We show that the species' distribution is associated with $37,517 \mathrm{~km}^{2}$ of the Ombrophilous Dense Forest in the Brazilian Atlantic Forest, and this conclusion is supported by species distribution modelling. The small red brocket deer is the largest endemic species in Brazil and may have the smallest geographical distribution of any Neotropical deer species. This species occupies fragmented landscapes
\end{abstract}

José Maurício Barbanti Duarte (Corresponding author), Ângela Cristina Talarico and Márcio Leite Oliveira Núcleo de Pesquisa e Conservação de Cervídeos, Departamento de Zootecnia, Universidade Estadual Paulista, Via de Acesso Paulo Donato Castellane, s/n, CEP 14884-900, Jaboticabal, São Paulo, Brazil. E-mail barbanti@fcav.unesp.br

AleXANdRe Vogliotti Universidade Federal da Integração Latino-Americana, Foz do Iguaçu, Paraná, Brazil

José Eduardo Garcia Universidade Federal de Pernambuco, Centro Acadêmico de Vitória, Vitoria de Santo Antão, Pernambuco, Brazil

Jesús E. Maldonado* Center for Conservation Genomics, Smithsonian Conservation Biology Institute, National Zoological Park, Washington, DC, USA

Susana Gonzáleż Genética de la Conservación, Departamento de Biodiversidad y Genética, Instituto de Investigaciones Biológicas Clemente Estable, Ministerio de Educación y Cultura, Montevideo, Uruguay

*Also at: Department of Vertebrate Zoology, National Museum of Natural History, Smithsonian Institution, Washington, DC, USA

$\dagger$ †lso at: Sección Genética Evolutiva, Facultad de Ciencias, Universidad de la República Oriental del Uruguay, Montevideo, Uruguay

Received 18 September 2015. Revision requested 4 November 2015 Accepted 18 April 2016. First published online 11 October 2016. and is threatened by human encroachment, poaching, and predation by dogs, and based on our findings we recommend policy intervention for conservation planning of the Ombrophilous Dense Forest.

Keywords Atlantic Forest, Brazil, Cervidae, Cytochrome b, geographical range, Mazama bororo, non-invasive sampling

\section{Introduction}

The small red brocket deer Mazama bororo is one of I the most threatened, elusive and poorly known Neotropical deer. It is categorized as Vulnerable on the IUCN Red List (Duarte, 2008). The species inhabits remnants of the Atlantic Forest (Duarte \& Jorge, 2003; Weber \& González, 2003; Duarte, 2008; Duarte et al., 2008), the second largest rainforest of the American continent, which once stretched almost continuously along the Brazilian coast, extending inland in the south and into eastern Paraguay and north-eastern Argentina (Tabarelli et al., 2005). This biome may hold up to $8 \%$ of all species of flora and fauna (Silva \& Casteleti, 2003), and has a history of intensive habitat loss and fragmentation caused by human activity. More than $88 \%$ of the original forest cover has already been cleared, and the land converted to non-forest use (Ribeiro et al., 2009).

The small red brocket deer is difficult to observe because it inhabits dense forests. In addition, morphological similarities with sympatric brocket deer species preclude the use of traditional methodologies for detection and species identification (Duarte \& Jorge, 2003; Vogliotti \& Duarte, 2009, 2010). Skins and skulls from Brazilian scientific collections revealed size, coloration and pelage differences between specimens taken from within the extent of occurrence of $M$. bororo and specimens of red brocket deer M. americana from other regions of Brazil (Rossi, 2000). Although some morphological characteristics (weight, height, length of body, circumference of thorax, and length of metacarpus and metatarsus) may be potential discriminators of the species in living individuals or when entire carcasses are available (Duarte \& Jorge, 2003), these characteristics are difficult to evaluate in the field using camera traps or even visual encounter data. 
Because of these morphological similarities, it was only through karyotype characterization and subsequent molecular confirmation (Duarte et al., 2008) that the small red brocket deer was identified and described as a distinct species from the red brocket deer $(2 \mathrm{n}=32$ and $2 \mathrm{n}=52$, respectively; Duarte \& Jorge, 2003). Karyotyping has been proposed as the most reliable tool to distinguish $M$. bororo from other sympatric species of brocket deer (Duarte, 1996; Duarte \& Merino, 1997; Duarte \& Jorge, 2003; Vogliotti \& Duarte, 2010). However, to obtain karyotypes using cytogenetic protocols it is necessary to capture live individuals and collect fresh samples (blood and skin), which is difficult for this elusive species (Duarte et al., 1999). Efforts to locate and capture the deer are expensive, time consuming and infeasible. We conducted intensive field work surveys for 4 years and were able to locate and capture only five freeliving M. bororo (Vogliotti \& Duarte, 2009). This difficulty prompted us to develop faster, more efficient methods to detect this rare and elusive species and determine its geographical range, using non-invasive sampling of faecal material in combination with molecular markers (polymerase chain reaction-restriction fragment length polymorphism, PCRRFLP; González et al., 2009).

Visually locating deer faeces in dense forest is challenging (Rivero et al., 2004). To maximize the number of faecal samples detected during surveys we used scat detection dogs, which have been proven to significantly improve the detection of faeces from rare and elusive species (Smith et al., 2001; Oliveira et al., 2012), and have been used effectively to locate faecal samples from a diversity of carnivores (Smith et al., 2003, 2005; Harrison, 2006; Long et al., 2007; Reed et al., 2011; Vynne et al., 2011), Xenarthrans (Vynne et al., 2011), and North Atlantic right whales Eubalaena glacialis (Rolland et al., 2006).

It is challenging to predict the ranges of rare and elusive species precisely but this information is critical for conservation planning. One approach that has become increasingly important is species distribution modelling (Guisan et al., 2013), which is used to derive spatially explicit predictions of environmental and ecological suitability for a particular species. This is achieved by the identification of statistical relationships between observations of species occurrence and environmental or ecological descriptors that characterize the species' ecological niche. Species distribution modelling has the potential to play a critical role in supporting spatial conservation decision making (Addison et al., 2013). It has proven to be particularly useful when occurrence data are limited, and the results can be used to inform planning for new surveys (Pearson, 2007).

To determine the geographical range of $M$. bororo more accurately we conducted intensive non-invasive surveys using scat detection dogs in all potential areas of occurrence, and used the occurrence data in species distribution modelling. Our results confirmed that the small red brocket deer has the smallest geographical distribution of any deer species described to date, and its distribution appears to have decreased significantly over the past 2 centuries. We therefore suggest there is an urgent need to develop conservation and restoration actions for all remnants of the Atlantic Forest, and recommend that conservation efforts should target the reduction of the edge effects of forest fragments, palm heart exploitation and poaching.

\section{Study area}

The sampling sites were selected based on the proposed distribution of $M$. bororo in the Serra do Mar coastal forests ecoregion (Duarte, 1996). We focused on sampling in the Ombrophilous Dense Forest, and we also included other associated formations, such as the Mixed Ombrophilous Forest (Araucaria moist forest), Semideciduous Seasonal Forest (Paraná-Paraíba interior forests) and some ecotones. The chosen areas were mainly government protected areas and private reserves $>1,000$ ha. Additionally, we surveyed buffer areas surrounding protected areas where the scat detection dogs were forbidden from entering. These buffer areas were adjacent to the protected areas and had similar ecological characteristics. In total, we surveyed 46 sites in the states of São Paulo, Paraná, Santa Catarina, Bahia, Espírito Santo and Minas Gerais (Fig. 1; Table 1).

\section{Methods}

\section{Sample collection and storage}

Searches for faecal samples were conducted during June 2003-October 2012 by one or more observers and a handler with two scat detection dogs. The dogs were trained by the military police of São Paulo State narcotics detection programme and worked freely off-lead. The searches were conducted along natural trails and the borders of rivers and forests. Although the Atlantic Forest is continually affected by deforestation and exploitation (Galindo-Leal \& Câmara, 2005), we had to assume that no changes in habitat or deer distribution occurred over the time period of the sampling. As we aimed only to record presence data, the sampling effort was not recorded in detail (e.g. time in hours, or meters surveyed) and the duration of surveys varied from 1 day in some areas to up to 1 week in others. This sampling scheme precluded gathering true absence data.

The collected faecal samples were stored in absolute ethanol in $50 \mathrm{ml}$ sterile polypropylene conical tubes. The samples were identified by location name, collection number, geographical coordinates and date. When multiple faecal pellets were found accumulated in the same location they were considered to belong to a latrine. In these cases, to avoid resampling the same individuals, we collected only 


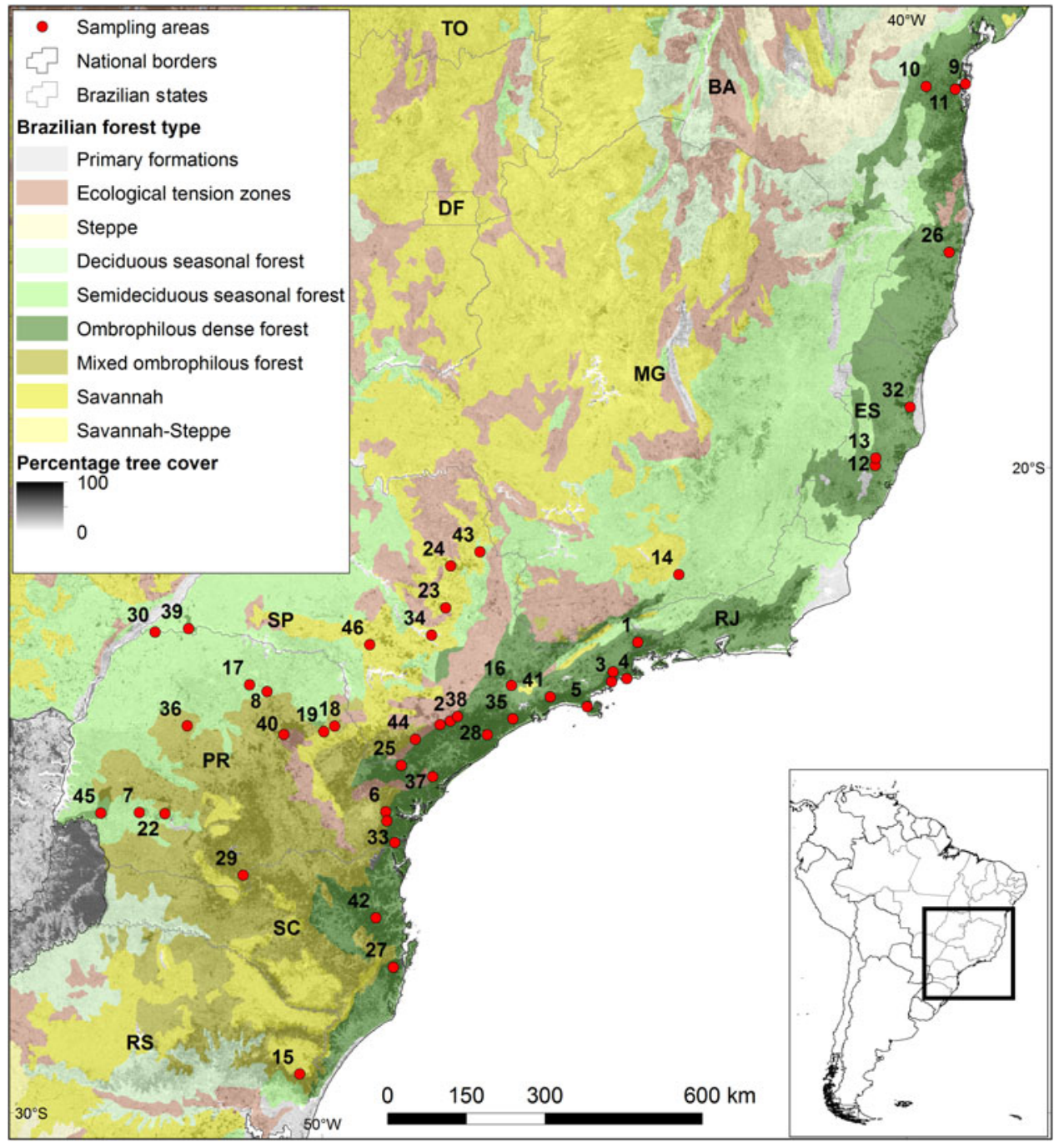

FIg. 1 Sampling sites (Table 1) for deer scat across the Brazilian Atlantic Forest. Forest type is categorized according to Veloso et al. (1991), and percentage tree cover is based on Hansen et al. (2003). representative samples from clusters of pellets found at separate locations.

\section{DNA extraction and PCR-RFLP}

Faecal DNA extractions were performed using a Qiamp DNA Stool Mini Kit (QIAGEN, Hilden, Germany) according to the manufacturer's protocol. Extractions were carried out in a dedicated room free of PCR products to prevent contamination.

PCR amplifications of a $224 \mathrm{bp}$ fragment of Cytochrome b were performed in a final volume of $25 \mu \mathrm{l}$ and contained $1 \times$ Invitrogen buffer, $1.5 \mathrm{mM} \mathrm{MgCl}_{2}$, $0.1 \mathrm{mM}$ of each dNTP (deoxynucleotide triphosphate), $1 \mathrm{pmol} \mu \mathrm{l}^{-1}$ of each primer (IDMAZ224L and IDMAZ224H; González et al., 2009), 1.0 U Taq DNA Polymerase (Invitrogen), and 6o-100 ng $\mu \mathrm{l}^{-1}$ of faecal DNA. For the thermal profile we followed González et al. (2009). We included a negative control in each set of PCRs performed, to detect any possible contamination.

The amplified $224 \mathrm{bp}$ fragment of Cytochrome b contains three informative restriction sites that can discriminate between $M$. bororo and its sympatric brocket deer species M. americana, M. nana and M. gouazoubira (González et al., 2009). The presence of the restriction site for ECORII or BSTNI in position 160 was used to confirm species identification because it has been demonstrated to be unique to M. bororo (González et al., 2009). PCR products that failed to digest were subjected to cycle sequencing to verify species identification. PCR products were purified using a Zymoclean ${ }^{\mathrm{TM}}$ DNA Recovery Kit (Zymo Research, Irvine, USA), and sequenced using an ABI Prism 3730xl DNA Analyzer (Applied Biosystems, Foster City, USA) with the IDMAZ224L and IDMAZ224H (forward and reverse) primers described in González et al. (2009). Sequences were analysed using MEGA 5.1 (Tamura et al., 2011).

\section{Species distribution modelling procedures}

We developed species distribution models using MaxEnt v.3.3.3 (Phillips et al., 2006), the most adequate and frequently used software for species distribution modelling (Baldwin, 
TABLE 1 Sampling localities (see numbered locations in Fig. 1), total number of faecal samples collected, and number of samples identified, by Mazama species.

\begin{tabular}{|c|c|c|c|c|c|c|}
\hline \multirow[b]{2}{*}{ Locality $\left(\right.$ State $\left.^{\star}\right)$} & \multicolumn{6}{|c|}{ No. of samples identified } \\
\hline & Total & M. bororo & M. americana & M. nana & M. gouazoubira & Unknown \\
\hline 1. Serra da Bocaina National Park (SP) & 0 & 0 & 0 & 0 & 0 & 0 \\
\hline 2. Parque do Zizo Private Reserve (SP) & 0 & 0 & 0 & 0 & 0 & 0 \\
\hline 3. Serra do Mar State Park, Santa Virgínia (SP) & 0 & 0 & 0 & 0 & 0 & 0 \\
\hline 4. Serra do Mar State Park, Picinguaba (SP) & 0 & 0 & 0 & 0 & 0 & 0 \\
\hline 5. Serra do Mar State Park, São Sebastião (SP) & 0 & 0 & 0 & 0 & 0 & 0 \\
\hline 6. Pico do Marumbi State Park (PR) & 0 & 0 & 0 & 0 & 0 & 0 \\
\hline 7. Rio Guarani State Park (PR) & 0 & 0 & 0 & 0 & 0 & 0 \\
\hline 8. Mata do Barão Private Reserve (PR) & 0 & 0 & 0 & 0 & 0 & 0 \\
\hline 9. Pratigi Environmental Protection Area (BA) & 0 & 0 & 0 & 0 & 0 & 0 \\
\hline 10. Fazenda Fugidos (BA) & 0 & 0 & 0 & 0 & 0 & 0 \\
\hline 11. Fazenda Michelin (BA) & 0 & 0 & 0 & 0 & 0 & 0 \\
\hline 12. Santa Lucia Biological Station (ES) & 0 & 0 & 0 & 0 & 0 & 0 \\
\hline 13. Fazenda Lombardia (ES) & 0 & 0 & 0 & 0 & 0 & 0 \\
\hline 14. Serra do Ibitipoca (MG) & 0 & 0 & 0 & 0 & 0 & 0 \\
\hline 15. FLONA São Francisco de Paula (RS) & 0 & 0 & 0 & 0 & 0 & 0 \\
\hline 16. Jaraguá State Park (SP) & 0 & 0 & 0 & 0 & 0 & 0 \\
\hline 17. Mata dos Godoy State Park (PR) & 1 & 0 & 0 & 0 & 0 & 1 \\
\hline 18. Fazenda Barra Mansa (PR) & 3 & 0 & 0 & 0 & 0 & 3 \\
\hline 19. Fazenda São Nicolau (PR) & 4 & 0 & 0 & 0 & 0 & 4 \\
\hline 20. Serra do Mar State Park, Cunha-Indaiá (SP) & 1 & 0 & 1 & 0 & 0 & 0 \\
\hline 21. Pau-Oco State Park (PR) & 1 & 0 & 0 & 1 & 0 & 0 \\
\hline 22. ARAUPEL (PR) & 1 & 0 & 1 & 0 & 0 & 0 \\
\hline 23. Itirapina Ecological Station (SP) & 1 & 0 & 0 & 0 & 1 & 0 \\
\hline 24. Jataí Ecological Station (SP) & 21 & 0 & 0 & 0 & 1 & 20 \\
\hline 25. Lauraceas State Park (PR) & 2 & 0 & 0 & 2 & 0 & 0 \\
\hline 26. Pau-Brasil National Park (BA) & 2 & 0 & 0 & 0 & 2 & 0 \\
\hline 27. Serra do Tabuleiro State Park (SC) & 3 & 2 & 0 & 0 & 0 & 1 \\
\hline 28. Serra do Mar State Park, Pedro de Toledo (SP) & 3 & 0 & 0 & 0 & 3 & 0 \\
\hline 29. Araucárias State Park (PR) & 4 & 0 & 0 & 3 & 0 & 1 \\
\hline 30. Caiuá Ecological Station (PR) & 5 & 0 & 5 & 0 & 0 & 0 \\
\hline 31. Carlos Botelho State Park (SP) & 10 & 5 & 0 & 0 & 0 & 5 \\
\hline 32. Fazenda Boa Sorte (ES) & 6 & 0 & 0 & 0 & 6 & 0 \\
\hline 33. Guaratuba Environmental Protection Area (PR) & 6 & 2 & 0 & 4 & 0 & 0 \\
\hline 34. Fazenda Barreiro Rico (SP) & 8 & 0 & 8 & 0 & 0 & 0 \\
\hline 35. Serra do Mar State Park, Curucutu (SP) & 8 & 0 & 3 & 0 & 5 & 0 \\
\hline 36. Lago Azul State Park (PR) & 9 & 0 & 5 & 0 & 4 & 0 \\
\hline 37. Jacupiranga State Park (SP) & 9 & 6 & 0 & 0 & 3 & 0 \\
\hline 38. Fazenda João XXIII (SP) & 11 & 10 & 1 & 0 & 0 & 0 \\
\hline 39. Morro do Diabo State Park (SP) & 13 & 0 & 8 & 0 & 5 & 0 \\
\hline 40. Monte Alegre Private Reserve (PR) & 13 & 0 & 1 & 0 & 12 & 0 \\
\hline 41. Biritiba-Mirim (SP) & 19 & 0 & 0 & 0 & 19 & 0 \\
\hline 42. Serra do Itajaí National Park (SC) & 28 & 4 & 0 & 21 & 0 & 3 \\
\hline 43. Cajuru Legal Reserve (SP) & 52 & 0 & 45 & 0 & 0 & 7 \\
\hline 44. Intervales State Park (SP) & 87 & 87 & 0 & 0 & 0 & 0 \\
\hline 45. Iguaçu National Park (PR) & 112 & 0 & 80 & 20 & 0 & 12 \\
\hline 46. Santa Bárbara Ecological Station (SP) & 112 & 0 & 0 & 0 & 111 & 1 \\
\hline Total samples & 555 & 116 & 158 & 51 & 172 & 58 \\
\hline
\end{tabular}

*SP, São Paulo; PR, Paraná; BA, Bahia; ES, Espírito Santo; MG, Minas Gerais; RS, Rio Grande do Sul; SC, Santa Catarina

2009). In comparison to other approaches MaxEnt performs well with small sample sizes (Hernandez et al., 2006).

Occurrence data were based on only 19 sample locations, following the exclusion of multiple records in the same pixel (c. $1 \mathrm{~km}^{2}$ ). We used $70 \%$ of the points to train the model and $30 \%$ to test the model. They were sampled by bootstrapping 10 random partitions with replacement (Pearson, 2007). 


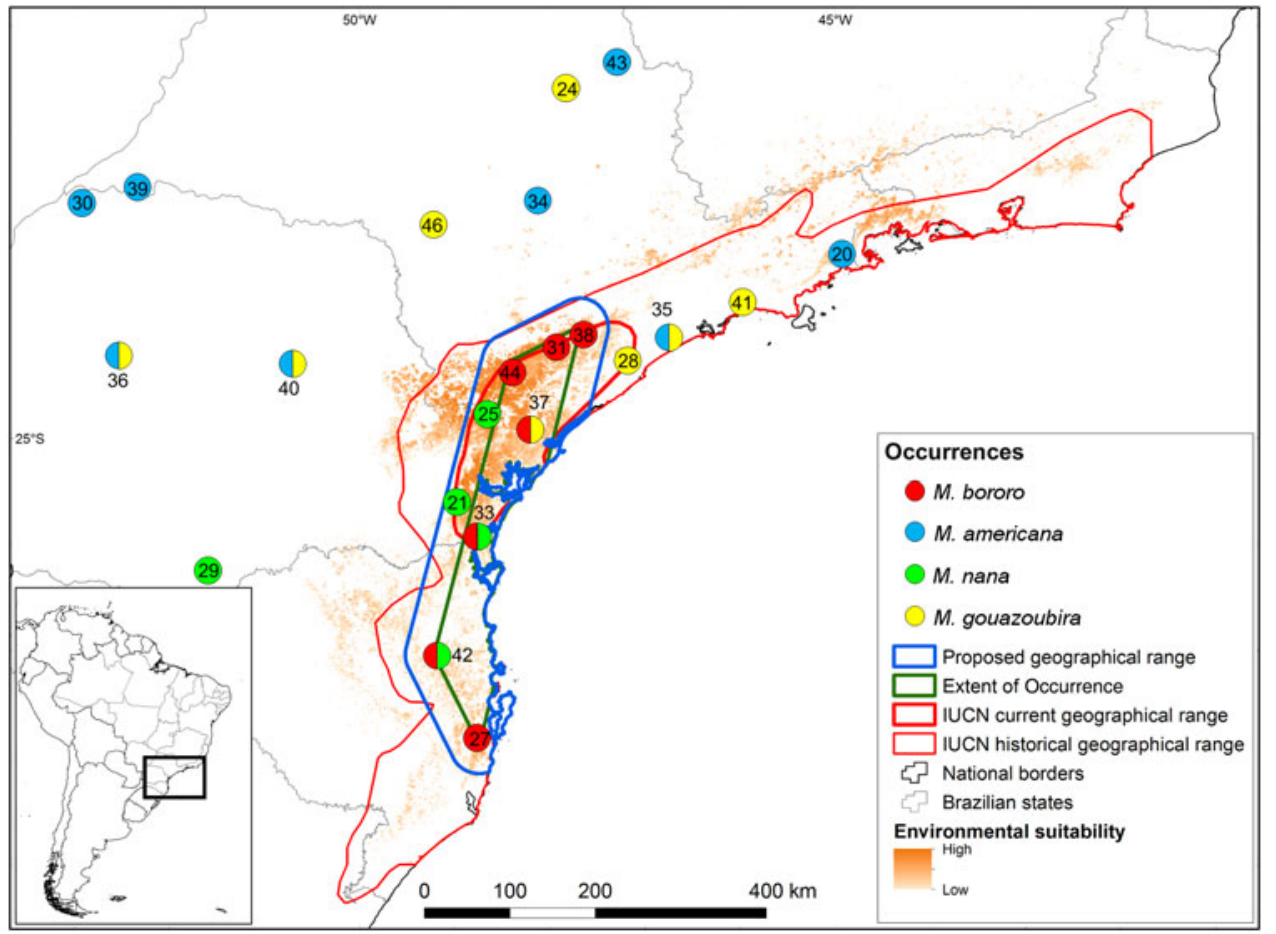

FIG. 2 Species distribution model for Mazama bororo, with the extent of occurrence, IUCN geographical ranges, the proposed geographical range, and locations of occurrence (numbered as in Table 1) of Mazama species. A circle with two colours indicates that two species were found at the same sampling site.
The environmental layers were composed of bioclimatic variables, including mean annual temperature (bio1), temperature seasonality (the standard deviation, multiplied by 100 , of the monthly temperature; bio4), annual precipitation (bio12), precipitation seasonality (bio15), and precipitation of the driest month (bio14), from the WorldClim database (Hijmans et al., 2005), percentage tree cover in 2000-2001 (Hansen et al., 2003), altitude (Valeriano, 2008), and slope obtained from the AMBDATA database. We also produced raster maps with Euclidean distance from maps of the protected areas (Ministério do Meio Ambiente, 2015), forest remnants (Ribeiro et al., 2009) and the Ombrophilous Dense Forest (Veloso et al., 1991). The environmental layers were selected based on variables that had a high likelihood of being associated with $M$. bororo habitat in the humid coastal Atlantic Forest distributed throughout mountain chains.

All layers were trimmed to match the limits of the Atlantic Forest (modelling scope) and rescaled to a resolution of $1 \mathrm{~km}^{2}$. All spatial analyses were conducted using ArcMap v. 10.3.1 (ESRI, Redlands, USA). We evaluated the degree of correlation between environmental variables using PAST 3.06 (Hammer et al., 2001). Two bioclimatic variables (mean annual temperature and precipitation of the driest month) were removed because of their high correlation $(r>|0.75|)$ with altitude and precipitation seasonality, respectively. We performed a principal components analysis to select the most explicative variables. The variables identified and subsequently used in the MaxEnt analysis were bio12, bio15, bio4, distance from Ombrophilous Dense Forest, altitude, and percentage tree cover. The resulting model was evaluated using the area under the receiver operating curve, omission error and a two-proportion binomial test (Fielding \& Bell, 1997; Elith et al., 2006; Pearson, 2007; Phillips \& Dudík, 2008). To predict the species' distribution we assumed only the probabilistic values over the minimum training presence logistic threshold.

\section{Results}

\section{Species identification from scat samples}

We collected 555 deer scat samples from 30 of the 46 surveyed areas. PCR reactions amplified 497 (89\%) of the samples successfully. The RFLP reaction failed for PCR products from 18 samples $(3.2 \%)$. For these samples we then proceeded to sequence the PCR products directly, but only 10 of the PCR products yielded sequences of sufficient quality to determine species. The PCR-RFLP reaction and sequencing indicated that 116 (23\%) samples were from $M$. bororo. The remaining samples were from M. gouazoubira (172; $34 \%)$, M. americana $(158 ; 31 \%)$ and $M$. nana $(51 ; 10 \%)$. The small red brocket deer was positively identified in only seven localities within the states of São Paulo, Paraná and Santa Catarina (Fig. 2).

\section{Geographical range}

The size of the area obtained by linking external points of positive occurrence (extent of occurrence) was $20,000 \mathrm{~km}^{2}$, encompassing the Serra do Mar and Serra de Paranapiacaba from the states of São Paulo, Paraná and 
Santa Catarina. This region encompasses the Ombrophilous Dense Forest, an Atlantic Forest formation that is close to the Brazilian coastline, at $8-29^{\circ} \mathrm{S}$. We did not detect M. bororo samples in the states of Espírito Santo or Bahia. To define the proposed geographical range we added a buffer zone of $30 \mathrm{~km}$ to the extent of occurrence, except for the areas that extended to the ocean (Fig. 2). This yielded a geographical range of $41,714 \mathrm{~km}^{2}$, which is the best estimate of the actual distribution of the species to date.

\section{Species distribution modelling}

The model developed in MaxEnt (Fig. 2) was evaluated satisfactorily by the mean area under the curve (o.9782 \pm SD 0.0078$)$ external test with 10 random partitions and was significantly different from random $(\mathrm{P}<0.01)$ in a two proportion binomial test. The omission error was o.14. The model predicted the occurrence of $M$. bororo with the highest values of environmental suitability at Serra de Paranapiacaba, Guaraqueçaba Environmental Protection Area and Serra do Tabuleiro State Park (Fig. 2). The variables that most contributed to the species distribution model were percentage tree cover $(62.4 \%)$, distance from Ombrophilous Dense Forest (18.6\%) and temperature seasonality (10.9\%).

\section{Discussion}

Species of the genus Mazama display a high degree of morphological similarity (Duarte et al., 2008), making it difficult to distinguish them by direct field observations or camera traps (Vogliotti \& Duarte, 2010). Our findings confirmed the sympatry of $M$. bororo, M. americana, M. nana and M. gouazoubira by the identification of more than one of the species in nine of 46 localities sampled. Furthermore, we found one or more sympatric Mazama species in three of seven localities (42.8\%) where M. bororo was also detected. We detected $M$. nana in sympatry with $M$. bororo in two separate localities, and with M. gouazoubira in another locality (Fig. 2). These two species (M. nana and $M$. gouazoubira) are more common than $M$. bororo in human-altered and less pristine environments (Vogliotti, 2008). This suggests that the more suitable habitats used by $M$. bororo are being altered even in the protected areas where our sampling took place. This change in $M$. bororo habitat may be the result of edge effects (Ribeiro et al., 2009), palm heart exploitation, poaching (Vogliotti \& Duarte, 2012) or global climatic changes (Allen et al., 2010). We hypothesize that $M$. nana may be invading areas that were formerly occupied only by $M$. bororo and that this invasion may be facilitated by the degradation of the Ombrophilous Mixed Forest. In addition, M. gouazoubira, which is known to be one of the brocket species with greater ecological plasticity (Pinder \& Leeuwenberg, 1997; Black-Décima et al., 2010) and resistance to anthropogenic habitat alteration (Rodrigues et al., 2014), has been extending its range to include deforested areas that were previously covered with Atlantic Forest. The role of competition in the distribution and survival of sympatric brocket species in this area needs careful evaluation to define and mitigate better the effect of habitat changes in conservation plans for the small red brocket.

Morphometric and morphological studies of skulls and skins from various Brazilian collections (Rossi, 2000) failed to clearly differentiate $M$. bororo from $M$. americana, although the data supported the presence of a partially differentiated population of M. americana distributed throughout the south coast of Brazil. These results were considered to be the most reasonable evidence of the historical distribution of $M$. bororo in the Atlantic Forest. It is important to note that the ranges of distribution established here and by Rossi (2000) were based on different methods, and there are many uncertainties involved in the reconstruction of the historical distribution. However, we suspect that the extent of the decline in distribution has been dramatic, as the species would have occupied the mountain ranges of the Serra de Paranapiacaba and the Serra do Mar, from the eastern part of the state of Santa Catarina to the state of São Paulo in the south and south-east regions of Brazil. We estimate that the historical geographical range was $114,120 \mathrm{~km}^{2}$ (Fig. 2).

The original proposed extent of the geographical distribution of M. bororo was based on the localities of provenance of the captive individuals used in the karyotypic characterization that resulted in the species description. These individuals originated in the cities of Capão Bonito, Barra do Turvo, São José dos Pinhais and Paranaguá and these localities were used to set the distribution limits to the south of São Paulo and east of Paraná states (Duarte, 1992, 1996; Duarte \& Jorge, 2003; Vogliotti \& Duarte, 2009).

Our survey results support an extension of the geographical range of the small red brocket deer to the latitudes $23^{-}$ $28^{\circ} \mathrm{S}$ and to the longitudes $47-49^{\circ} \mathrm{W}$ (Fig. 2), encompassing $37,517 \mathrm{~km}^{2}$. This range is considered to be the extent of occurrence, similar to the current area of occupancy because it represents an ecological continuum constituted by protected areas. A comparison of the historical distribution of $114,120 \mathrm{~km}^{2}$ (Rossi, 2000) with our results suggests that there has been an $83 \%$ decline in the distribution over the last 2 centuries. Given its recent description and hypothesized geographical range, there is little historical evidence to facilitate evaluation of the effects of anthropogenic development on the original distribution of the small red brocket deer. Currently, the habitat in the species' area of occupancy is well-preserved, with few barriers to gene flow. If protected, habitat connectivity will help to maintain adequate levels of genetic diversity in the future. 
The small red brocket is the largest endemic animal of Brazil, with perhaps the smallest geographical distribution of any Neotropical deer species. It is categorized as Vulnerable on the IUCN Red List because of its small population size and ongoing decline inferred from poaching and habitat loss, and because all of the remaining individuals are from a single subpopulation (Duarte, 2008). It is threatened by human encroachment ( $70 \%$ of the Brazilian population lives within the original limits of the Atlantic Forest), poaching, and predation by dogs (Duarte, 2008).

Species distribution modelling indicates that the current geographical distribution reported by IUCN should be revised to encompass northern areas with high environmental suitability, as well as the southern part of the Serra do Tabuleiro State Park and Serra do Itajaí National Park, where we collected occurrence data. In addition, areas of high suitability where no sampling was carried out or no deer species were detected during sampling should be revisited to confirm presence or absence. We also suggest that future species distribution models incorporate variables based on patch size and connectivity. Species distribution modelling provides more detailed information than traditional distribution estimates as it gives a suitability index for each $1 \mathrm{~km}^{2}$ pixel instead of a continuous distribution of values. It increases our understanding of species' needs and gives support to conservation policies such as those for the design and establishment of protected and conservation priority areas.

We have demonstrated the importance of incorporating traditional field techniques with non-invasive sampling and sophisticated molecular tools to elucidate geographical range, extent of occurrence, and areas with the highest suitability for occupancy by the elusive small red brocket deer. Such information is essential in designing strategies for species conservation, particularly in the Neotropics, where new species with limited distributions are being discovered. Conservation efforts should aim more specifically to maintain the last remnants of the Atlantic Forest and to target the reduction of the edge effects of forest fragments, poaching and palm heart exploitation. M. bororo should be considered a flagship species and used as an indicator of the quality and restoration of the habitat.

\section{Acknowledgements}

This project was funded by the Projeto de Conservação e Utilização Sustentável da Diversidade Biológica Brasileira, Fundação de Amparo a Pesquisa do Estado de São Paulo, Conselho Nacional de Desenvolvimento Científico e Tecnológico (Brazil), Agencia Nacional de Investigación y Inovación, Programa de Desarrollo de las Ciencias Básicas, and Comisión Sectorial de Investigación Científica (Uruguay). We thank Renato Cheffer and Hermógenes Aparecido Torres for help with sample collection, and Instituto Brasileiro de Meio Ambiente, Instituto Chico Mendes de Conservação da Biodiversidade, Secretaria do Meio Ambiente do Estado do Paraná, Secretaria do Meio Ambiente do Estado de Santa Catarina and EUCATEX S.A. Indústria e Comércio, who authorized the collection of samples in the Conservation Units under their authority. Lillian Parker provided comments that greatly improved this article.

\section{Author contributions}

JMBD was the project coordinator and contributed to writing the article. ACT and JEG conducted laboratory analysis. AV contributed to non-invasive sampling and data management. MLO contributed to non-invasive sampling, laboratory analysis, distribution modelling, and writing the article. JEM provided scientific support and contributed to writing the article. SG provided scientific support, conducted laboratory analysis and contributed to writing the article.

\section{References}

Addison, P.F.E., Rumpff, L., Bau, S.S., Carey, J.M., Chee, Y.E., JARraD, F.C. et al. (2013) Practical solutions for making models indispensable in conservation decision-making. Diversity and Distributions, 19, 490-502.

Allen, C.D., Macalady, A.K., Chenchouni, H., Bachelet, D., MC Dowell, N., Vennetier, M. et al. (2010) A global overview of drought and heat-induced tree mortality reveals emerging climate change risks for forests. Forest Ecology and Management, 259, $660-684$.

BALDWIN, R.A. (2009) Use of maximum entropy modeling in wildlife research. Entropy, 11, 854-866.

Black-Décima, P., Rossi, R.V., Vogliotti, A., Cartes, J.L., Maffei, L., Duarte, J.M.B. et al. (2010) Brown brocket deer Mazama gouazoubira (Fischer, 1814). In Neotropical Cervidology (eds J.M.B. Duarte \& S. González), pp. 218-227. FUNEP, Jaboticabal, Brazil, and IUCN, Gland, Switzerland.

Duarte, J.M.B. (1992) Aspectos taxonômicos e citogenéticos de algumas espécies de cervídeos brasileiros. MSc thesis. Universidade Estadual Paulista 'Júlio de Mesquita Filho', Jaboticabal, Brazil.

Duarte, J.M.B. (1996) Guia de identificação de cervídeos brasileiros. FUNEP, Jaboticabal, Brazil.

DuARte, J.M.B. (2008) Mazama bororo. The IUCN Red List of Threatened Species v. 2014.3. Http://www.iucnredlist.org [accessed 30 March 2015].

Duarte, J.M.B., González, S. \& Maldonado, J.E. (2008) The surprising evolutionary history of South American deer. Molecular Phylogenetics and Evolution, 49, 17-22.

Duarte, J.M.B. \& Jorge, W. (2003) Morphologic and cytogenetic description of the small red brocket (Mazama bororo Duarte, 1996) in Brazil. Mammalia, 67, 403-410.

Duarte, J.M.B. \& Merino, M.L. (1997) Taxonomia e Evolução. In Biologia e conservação de cervídeos Sul-americanos: Blastoceros, Ozotoceros e Mazama (ed. J.M.B. Duarte), pp. 1-21. FUNEP, Jaboticabal, Brazil. 
Duarte, J.M.B., Ramalho, M.F.D., Lima, V.F.H. \& Jorge, W. (1999) A leukocyte cryopreservation technique for cytogenetic studies. Genetics and Molecular Biology, 22, 399-400.

Elith, J., Graham, C.H., Anderson, R.P., Dudik, M., Ferrier, S., Guisan, A. et al. (2006) Novel methods improve prediction of species' distributions from occurrence data. Ecography, 29, 129-151.

Fielding, A.H. \& Bell, J.F. (1997) A review of methods for the assessment of prediction errors in conservation presence/absence models. Environmental Conservation, 24, 38-49.

Galindo-Leal, C. \& CÂmara, I.G. (2005) Mata Atlântica: Biodiversidade, ameaças e perspectivas. Fundação SOS Mata Atlântica, Belo Horizonte, Brazil.

González, S., Maldonado, J.E., Ortega, J., Talarico, A.C., Bidegaray-Batista, L., Garcia, J.E. \& Duarte, J.M.B. (2009) Identification of the endangered small red brocket deer (Mazama bororo) using non invasive genetic techniques (Mammalia; Cervidae). Molecular Ecology Resources, 9, 754-758.

Guisan, A., Tingley, R., Baumgartner, J.B., Naujokaitis-Lewis, I., Sutcliffe, P.R., Tulloch, A.I.T. et al. (2013) Predicting species distributions for conservation decisions. Ecology Letters, 16, 1424-1435.

Hammer, Ø., Harper, D.A.T. \& Ryan, P.D. (2001) PAST: paleontological statistics software package for education and data analysis. Palaeontologia Electronica, 4, 1-9.

Hansen, M.C., De Fries, R.S., Townshend, J.R.G., Carroll, M., Dimiceli, C. \& Sohlberg, R.A. (2003) Global percent tree cover at a spatial resolution of 500 meters: first results of the MODIS vegetation continuous fields algorithm. Earth Interactions, 7, 1-15.

HARRISON, R.L. (2006) A comparison of survey methods for detecting bobcats. Wildlife Society Bulletin, 34, 548-542.

Hernandez, P.A., Graham, C.H., Master, L.L. \& Albert, D.L. (2006) The effect of sample size and species characteristics on performance of different species distribution modeling methods. Ecography, 29, 773-785.

Hijmans, R.J., Cameron, S.E., Parra, J.L., Jones, P.G. \& Jarvis, A. (2005) Very high resolution interpolated climate surfaces for global land areas. International Journal of Climatology, 25, 1965-1978.

Long, R.A., Donavan, T.M., Mackay, P., Zielinski, W.J. \& BuZas, J.S. (2007) Effectiveness of scat detection dogs for detecting forest carnivores. Journal of Wildlife Management, 71, 2007-2017.

Ministério do Meio Ambiente (2015) Http://www.mma.gov.br/ areas-protegidas/cadastro-nacional-de-ucs/dadosgeorreferenciados [accessed 10 March 2015].

Oliveira, M.L., Norris, D., Ramírez, J.F.M., Peres, P.H.F., Galetti, M. \& Duarte, J.M.B. (2012) Dogs can detect scat samples more efficiently than humans: an experiment in a continuous Atlantic Forest remnant. Zoologia, 29, 183-186.

Pearson, R.G. (2007) Species' distribution modeling for conservation educators and practitioners. Synthesis. American Museum of Natural History. Http://ncep.amnh.org [accessed 10 June 2016]

Phillips, S.J., Anderson, R.P. \& Schapire, R.E. (2006) Maximum entropy modeling of species geographic distributions. Ecological Modelling, 190, 231-259.

Phillips, S.J. \& Dudí, M. (2008) Modeling of species distributions with Maxent: new extensions and a comprehensive evaluation. Ecography, 31, 161-175.

Pinder, L. \& Leeunenberg, F. (1997) Veado-catingueiro (Mazama gouazoubira, Fischer, 1814). In Biologia e conservação de cervídeos Sul-americanos: Blastocerus, Ozotoceros e Mazama (ed. J.M.B. Duarte), pp. 6o-68. FUNEP, Jaboticabal, Brazil.

Reed, S.E., Bidlack, A.L., Hurt, A. \& Getz, W.M. (2011) Detection distance and environmental factors in conservation detection dog surveys. Journal of Wildlife Management, 75, 243-251.
Ribeiro, M.C., Metzger, J.P., Martensen, A.C., Ponzoni, F.J. \& Hirota, M.M. (2009) The Brazilian Atlantic Forest: how much is left, and how is the remaining forest distributed? Implications for conservation. Biological Conservation, 142, 1141-1153.

Rivero, K., Rumiz, D.I. \& Taber, A.B. (2004) Estimating brocket deer (Mazama gouazoubira and M. americana) abundance by dung pellet counts and other indices in seasonal Chiquitano forest habitats of Santa Cruz, Bolivia. European Journal of Wildlife Research, 50, 161-167.

Rodrigues, T.F., Cerveira, J.F. \& Duarte, J.M.B. (2014) Uso de áreas agrícolas por Mazama gouazoubira (Mammalia, Cervidae) no Estado de São Paulo. Iheringia Serie Zoologia, 104, 439-445.

Rolland, R.M., Hamilton, P.K., Kraus, S.D., Davenport, B., Gillett, R.M. \& Wasser, S.K. (2006) Faecal sampling using detection dogs to study reproduction and health in North Atlantic right whales (Eubalaena glacialis). Journal of Cetacean Research and Management, 8, 121-125.

Rossi, R.V. (2000) Taxonomia de Mazama Rafinesque, 1817 do Brasil (Artiodactyla, Cervidae). MS thesis. Universidade de São Paulo, São Paulo, Brazil.

Silva, J.M.C. \& CASteleti, C.H.M. (2003) Status of the biodiversity of the Atlantic Forest of Brazil. In The Atlantic Forest of South America: Biodiversity Status, Threats, and Outlook (eds C. Galindo-Leal \& I.G. Câmara), pp. 43-59. CABS \& Island Press, Washington, DC, USA.

Smith, D.A., Ralls, K., Cypher, B.L. \& Maldonado, J.E. (2005) Assessment of scat-detection dog surveys to determine kit fox distribution. Wildlife Society Bulletin, 33, 897-904.

Smith, D.A., Ralls, K., Davenport, B., Adams, B. \& Maldonado, J.E. (2001) Canine assistants for conservationists. Science, 291, 435.

Smith, D.A., Ralls, K., Hurt, A., Adams, B., Parker, M., Davenport, B. et al. (2003) Detection and accuracy rates of dogs trained to find scats of San Joaquin kit foxes. Animal Conservation, $6,339-346$.

Tabarelli, M., Pinto, L.P., Silva, J.M.C., Hirota, M. \& Bedê, L. (2005) Challenges and opportunities for biodiversity conservation in the Brazilian Atlantic Forest. Conservation Biology, 19, 695-700.

Tamura, K., Peterson, D., Peterson, N., Stecher, G., Nei, M. \& KUMAR, S. (2011) MEGA5: molecular evolutionary genetics analysis using maximum likelihood, evolutionary distance, and maximum parsimony methods. Molecular Biology and Evolution, 28, 2731-2739.

Valeriano, M.M. (2008) TOPODATA: Guia Para Utilização de Dados Geomorfométricos Locais. Http://mtc-m16c.sid.inpe.br/col/ sid.inpe.br/mtc-m18@8o/2008/o7.11.19.24/doc/publicacao.pdf [accessed 10 June 2016].

Veloso, H.P., Rangel-Filho, A.L.R. \& Lima, J.C.A. (1991) Classificação da vegetação brasileira, adaptada a um sistema universal. IBGE, Rio de Janeiro, Brazil.

Vogliotti, A. (2008) Partição de habitats entre os Cervídeos do Parque Nacional do Iguaçu. PhD thesis. Universidade de São Paulo, Piracicaba, Brazil.

Vogliotti, A. \& Duarte, J.M.B. (2009) Discovery of the first wild population of the small red brocket deer Mazama bororo (Artiodactyla: Cervidae). Mastozoologia Neotropical, 16, 499-503. Vogliotti, A. \& Duarte, J.M.B. (2010) Small red brocket deerMazama bororo. In Neotropical Cervidology (eds J.M.B. Duarte \& S. González), pp. 218-227. FUNEP, Jaboticabal, Brazil, and IUCN, Gland, Switzerland.

Vogliotti, A. \& Duarte, J.M.B. (2012) Veado-mateiro-pequeno (Mazama bororo). In Plano de Ação Nacional para a Conservação dos Cervídeos Ameaçados de Extinção (eds J.M.B. Duarte \& M.L. Reis), pp. 70-8o. ICMBio, Brasília, Brazil. 
Vynne, C., Skalski, J.R., Machado, R.B., Groom, M.J., Jácomo, A. T.A., Marinho-Filho, J. et al. (2011) Effectiveness of scat-detection dogs in determining species presence in a tropical savanna landscape. Conservation Biology, 25, 154-162.

Weber, M. \& GonZÁlez, S. (2003) Latin American deer diversity and conservation: a review of status and distribution. Ecoscience, 10, 443-454.

\section{Biographical sketches}

José Maurício Barbanti Duarte has worked on various aspects of the genetics, evolution, ecology and conservation of Neotropical deer species, particularly of the genus Mazama. Ângela Cristina
TALARICO is a biologist, and her MSc research focused on the distribution of the small red brocket deer. Alexandre Vogliotti has worked on small red brocket deer research and conservation, and is currently focused on deer ecology and conservation planning in the Atlantic Forest. José EduARdo Garcia is interested in the conservation genetics of Brazilian wildlife. MÁrcio Leite Oliveira's research is focused on distribution modelling and molecular ecology of brocket deer. JESÚs E. MALDONADO applies non-invasive genetic techniques to study conservation genetics, behavioural ecology and evolutionary genetics of a diversity of rare mammals. SUSANA GONZÁLEZ has conducted research in conservation biology for over 20 years and is co-chair of the IUCN SSC Deer Specialist Group. 